\title{
DARI DAMARWULAN KE JINGGOAN: DINAMIKA KESENIAN JANGER DI BANYUWANGI 1930'AN-1970
}

\author{
Hervina Nurullita \\ Program Studi Pendidikan Sejarah FKIP Universitas PGRI Banyuwangi \\ hervina.nurullita@gmail.com
}

\begin{abstract}
ABSTRAK
Penelitian ini berangkat dari sebuah pertanyaan bagaimana sejarah kesenian Janger yang sangat populer di Banyuwangi berkembang dengan pesat dan masih menjadi minat masyarakat dari tahun 1930'an sampai sekarang. Janger yang merupakan akulturasi dari Jawa, Bali dan Banyuwangi terus dilestarikan oleh para seniman pendukungnya. Janger identik dengan lakon Damarwulan-Minakjinggo pun menjadi perdebatan antara sejarah dan fiksi. Penelitian ini menggunakan metode penelitian sejarah yang terdiri dari heuristik, kritik, interpretasi dan historiografi. Hasil penelitian menyebutkan bahwa akulturasi dari seni Janger inilah yang menyebabkan kelestarian Janger Banyuwangi. Selain itu banyak dari seniman Banyuwangi yang menggantungkan hidupnya dari kesenian ini.
\end{abstract}

Kata Kunci: Janger, Banyuwangi, Damarwulan-Minakjinggo, Akulturasi.

\section{ABSTRACT}

This research come from the question history of Janger which too popular in Banyuwangi and still exist since 1930st until now. Janger is tradisional drama which acculturation from Java, Bali and Bali. Janger identic with story about Damarwulan-Minakjinggo. This story stil argued fiction or non fiction. Thi research using historical method such as heuristic, critic, interpretation and historiography. Result from this research know that acculturation between Java, Bali and Banyuwangi which make them sustainable until now. And the other many artist depends on their life in this drama.

Keywords: Janger, Banyuwangi, Damarwulan-Minakjinggo, Acculturation 


\section{PENDAHULUAN}

Damarwulan-Minakjinggo

adalah sebuah cerita dalam Serat

Damarwulan yang

berlatarbelakang kerajaan

Majapahit. Terdapat berbagai versi mengenai cerita DamarwulanMinakjinggo ini. Ada sastra tulis, dialog dalam wayang krucil, pertunjukan Langendriyan dan seni drama Damarwulan. Seni drama Damarwulan ini yang kemudian disebut Janger Banyuwangi. Naskah Damarwulan yang tertua menurut Brandes adalah naskah yang disalin oleh Roorda van Eysinga dalam "Handboek voor Land-en Volkenkunde" yang diketahui berangka tahun 1748 masehi (sebagai tahun penyalinannnya). Tahun 1748 merupakan masa pemerintahan Pakubuwana II (1725-1749) (Timoer, 1980). Pada periode selanjutnya naskah-naskah tentang cerita Damarwulan banyak ditulis ulang dan diperbanyak dari tahun ke tahun. Tidak diketahui secara pasti latar belakang penciptaan naskah Damarwulan pada masa Pakubuwana II. Sumber yang penulis temukan hanya menyebutkan bahwa Pakubuwana II merupakan satu dari dua Raja Surakarta yang dianggap sebagai pujangga besar (Margana, 2004). Peristiwa-peristiwa yang terjadi diseputar masa pemerintahan Pakubuwana II dapat mengantarkan penulis untuk mengetahui latar belakang penulisan serat Damarwulan.

Tulisan ini akan fokus pada perkembangan kesenian Janger di Banyuwangi yaitu sebuah gabungan seni drama, tari dan musik. Pada kesenian ini juga menggabungkan unsur Jawa, Bali dan Banyuwangi. Dan sampai saat ini kesenian ini termasuk salah satu kesenian yang popular di Banyuwangi. Janger di Banyuwangi menampilkan cerita yang diambil dari serat Damarwulan.

Menurut catatan Rekapitulasi Data Kesenian Se-Kabupaten Banyuwangi (Dinas Pariwisata, 2019) jumlah grup kesenian Janger di Banyuwangi 57 grup yang tersebar di seluruh wilayah 
kabupaten Banyuwangi. Jumlah ini menduduki posisi urutan kelima setelah kesenian Jaranan, hadrah, barong dan orkes. Sebagai kesenian tradisional Janger masih sangat dinikmati oleh masyarakat Banyuwangi dilihat dari banyaknya grup Janger yang masih eksis.

Berdasarkan uraian diatas maka rumusan masalah untuk penelitin ini adalah:
1. Bagaimana perjalanan sejarah Janger di Banyuwangi?

2. Bagaimana kesenin ini tetap lestari sampai sekarang?

\section{KAJIAN PUSTAKA}

Pada bab ini akan dipaparkan penelitian terdahulu yang berhubungan dengan Banyuwangi dan kesenian Janger yang ada di Banyuwangi.

Suhalik (2011) menjelaskan secara singkat tentang sejarah Kerajaan Blambangan, terbentuknya kota Banyuwangi dan segala peristiwa yang mengirinya. Juga dijelaskan tentang kesenian yang ada di Banyuwangi dari kesenian yang sudah punah seperti Wayang Piyutakhul juga dijelaskan tentang seni Janger yang ada di Banyuwangi.

Nurullita (2015) dalam penelitiannya menyebutkan tentang stigma Minakjinggo yang beredar di Banyuwangi tentang sosoknya yang digambarkan buruk rupa dalam berbagai narasi. Berbicara Minakjinggo tak lepas dari seni Janger Banyuwangi. Minakjinggo dan Damarwulan adalah tokoh sentral dalam pementasan Janger Banyuwangi. Stigma yang berkembang tersebut dikokohkan dengan simbol-simbol sehingga terkesan bahwa masyarakat Banyuwangi adalah keturunan raja yang jahat. Penggambaran tokoh Minakjinggo seperti ini menurut sudut pandang orang luar.

Bagi masyarakat Banyuwangi sendiri, Minakjinggo digambarkan dengan sosok yang rupawan, kesatria gagah perkasa seperti gambaran sosok seorang raja pada umumnya. Gambaran tersebut akan menjadi (seperti) nyata dengan adanya make up pada 
pementasan kesenian Janger. Penelitian tentang tata rias tokoh Minakjinggo ini telah dilakukan oleh Zhanah dan Lutfiati (2017). Pada penelitian ini dijelaskan bagaimana polesan make up atau yang biasa disebut dengan make up karakter dapat menghidupkan peran yang diinginkan.

\section{METODE PENELTTIAN}

Metode yang digunakan dalam penelitian ini adalah metode sejarah. Menurut Gottschlak (1975) metode sejarah adalah proses menguji dan menganalisis rekaman peninggalan masa lalu. Metode sejarah mempunyai empat langkah yaitu heuristic, kritik, interpretasi dan historiografi.

Pada penelitian ini langkah heuristik dilakukan dengan cara mencari sumber. Sumber tertulis diperoleh dari buku, arsip, penelitian terdahulu tentang Janger. Sedangkan sumber lisan yang diperoleh adalah hasil wawancara dengan pemain Janger yang masih eksis sampai sekarang. Pemain Janger yang penulis temui adalah Pak Sugiyo, Pak Heri. Dan
Pak Paeran. Selain pemain Janger sumber juga digali dari budayawan dan sejarawan. Budayawan dan sejarawan diwakili oleh Pak Sahuni dan Pak Suhalik.

Proses kritik sumber dilakukan dengan membandingkan hasil wawancara antara satu informan dengan informan lainnya. Penulis juga membandingkan hasil wawancara dengan sumber documenter lainnya.

Setelah data-data terkumpul penulis menggabungkan faktafakta yang telah diperoleh sehingga menghasilkan informasi yang relevan. Proses ini disebut sebagai tahap interpretasi. Sedangkan historiografi adalah proses penulisan artikel ini.

\section{PEMBAHASAN}

Sebagai pusat kebudayaan Jawa, Surakarta dan Yogyakarta adalah tempat bertumbuh suburnya berbagai seni dan budaya. Cerita DamarwulanMinakjinggo pun lahir dari sini. Cerita ini sangat disenangi oleh masyarakat Jawa Tengah. Lambat laun cerita tentang Damarwulan- 
Minakjinggo tersebar ke berbagai daerah. Tersebarnya cerita ini dikarenakan, isi cerita yang bagus dan menjadi hiburan bagi masyarakat. Kepopuleran cerita tersebut menjadikannya disalin ulang oleh penulis Jawa maupun penulis Barat (Nurullita, 2015). Menurut Arifin (1995) cerita Damarwulan-Minakjinggo dibawa ke Banyuwangi pada masa Arya Suganda, seorang Bupati Banyuwangi yang berasal dari Surakarta.

Penulis membagi cerita perkembangan DamarwulanMinakjinggo kedalam dua sub bab: a. Fase Perkembangan Damarwulan Jawa Tengahan Awal munculnya pementasan tentang cerita Damarwulan dapat dijumpai pada kesenian Langendriyan. Langendriyan merupakan salah satu bentuk opera tari Jawa. Dalam pementasannya drama tari ini menggunakan dialog puisi berupa tembang macapat. Dialog yang menggunakan tembang macapat, sajian vokalnya disebut palaran.
Selain menggunakan tembang macapat juga menggunakan bentuk tembang gedhe dan tembang tengahan (Muljono, tanpa tahun).

Pada mulanya kesenian Langendriyan berkembang di Yogyakarta dan Surakarta (Mangkunagaran). Di Yogyakarta Langendriyan lahir pada tahun 1876 yang diciptakan oleh K.G.P.A Mangkubumi atas gagasan K.R.T Purwadiningrat semasa pemerintahan Sri Sultan Hamengkubawana VI (1855-1877). Langendriyan Yogyakarta berawal dari kebiasaan Macapatan yang dilakukan pada saat bulan Ramadhan. Karena pada bulan Ramadhan kegiatan karawitan dihentikan sementara untuk menghormati orang yang menjalankan ibadah puasa. Sebagai bahan Macapatan tersebut, K.R.T Purwadiningrat memilih serat Damarwulan karena tokoh-tokoh utamanya sangat menarik. Langendriyan Yogyakarta ditarikan oleh penari laki-laki karena pada waktu itu menjadi hal yang tabu jika seorang wanita menari kecuali 
tari Bedaya dan Serimpi. Penari laki-laki itu menari dengan jongkok atau laku dhodhok dan dipertunjukkan di luar tembok keraton (Widyastutiningrum, 2006).

Pada tahun 1890 Adipati Danureja VI menciptakan Langendriyan khusus yang diberi nama Langendriyan Mandrawanara. Langendriyan Mandrawanara merupakan drama tari yang membawakan cerita Ramayana. Penciptaan kesenian ini diawali oleh ketertarikan Adipati Danureja VI terhadap bidang kesenian dan adanya larangan mempergelarkan tari yang berasal dari keraton Yogyakarta diluar tembok keraton. Terlebih jika tarian tersebut diciptakan oleh seorang Sultan. Akhirnya Adipati Danureja VI berhasil menciptakan drama tari yang berbeda dengan wayang wong, baik dari segi teknik maupun dialognya. Genre baru ini dapat diterima oleh masyarakat Yogyakarta. Pada tahun 1930-an mulai berdiri grup-grup Langendriyan Mandrawanara di desa-desa dan sering ditampilkan dalam berbagai acara di lingkungan masyarakat (Soedarsono, 1999).

Langendriyan

Mangkunagaran diciptakan pada tahun 1881 oleh R.M.H Tandhakusuma yang diprakarsai oleh Godlieb seorang pengusaha batik di Surakarta. Lahirnya kesenian Langendriyan Mangkunagaran dilatarbelakangi oleh kebiasaan nembang macapat yang dilakukan oleh para wanita pembatik (yang bekerja di rumah Godlieb) untuk mengatasi kejenuhan saat sedang melakukan pekerjaannya. Dari situlah Godlieb ingin membuat sebuah kesenian dari kebiasaan para pekerjanya itu. Maka Godlieb meminta kepada R.M.H Tandhakusuma untuk merealisasikannya. Langendriyan Mangkunagaran ditarikan oleh penari wanita yang kemudian disebut sebagai Langendriyan Mandraswara. Mandraswara berarti suara yang indah. Dengan demikian

Langendriyan Mandraswara bisa dimaknai sebagai pertunjukan hiburan 
dengan suara yang indah

(Widyastutiningrum, 2006).

Setelah R.M.H Tandhakusuma

berhasil menciptakan kesenian Langendriyan Madraswara, usaha batik Godlieb mengalami kemunduran sehingga Godlieb bangkrut dan Langendriyan Mandraswara terbengkalai. Atas usul R.M.H Tandhakusuma dan ijin dari Mangkunagara IV kesenian Langendriyan Mandraswara dikembangkan di keraton Mangkunagaran.

Langendriyan Mandraswara terus mengalami perbaikan dan pengembangan bentuk penyajiannya. Pada masa Mangkunagara $\mathrm{V}$ disusun tari dengan tokoh Minakjinggo, Damarwulan dan Dayun. Pertunjukan ini terkenal dengan nama Langendriyan Telu. Langendriyan Mandaraswara mengalami perkembangan pesat pada masa pemerintahan Mangkunagaran VII (1916-1944). Dibentuk abdi dalem khusus sebagai pendukung kegiatan tari dan karawitan terutama

Langendriyan. Selain itu Langendriyan Mandraswara diperankan oleh tujuh orang pemain yang kemudian dikenal dengan sebutan Langendriyan Pitu. Tujuh orang tersebut memerankan tokoh Damarwulan, Minakjinggo, Dayun, Sabdapalon, Nayagenggong, Dewi Wahita dan Dewi Puyengan. Selain itu juga dilakukan penyempurnaan terhadap gerak tari dan busana yang menjadi khas Mangkunagaran. Lakon yang diperankan pada waktu itu antara lain Damarwulan Ngarit, Ronggolawe Gugur, Minakjinggo Lena dan Pernikahan Ratu Ayu dengan Damarwulan.

Terdapat perbedaan antara bentuk sajian Langendriyan Yogyakarta dengan Langendriyan Mangkunagaran. Perbedaan pokok terletak pada garapan tari dan peraganya. Garapan tari Langendriyan Yogyakarta dilakukan dengan posisi jengkeng atau berlutut. Garapan tari Langendriyan Mangkunagaran dilakukan dengan berdiri, walaupun pada awalnya dilakukan 
dengan posisi jengkeng dan laku dhodhok. (Widyastutiningrum, 2006). Langendriyan Yogyakarta seluruhnya ditarikan oleh penari pria, meskipun menampilkan peran wanita tetapi selalu ditarikan oleh seorang pria. Hal ini dilandasi oleh tata cara dan etika feodal yang tidak membenarkan adanya pergaulan yang terlalu dekat antara pria dan wanita (Soedarsono, 1979). Sementara itu semua penari Langendriyan Mangkunagaran adalah seorang wanita. Peran pria juga ditarikan oleh seorang wanita. Humardani menyebutnya dengan istilah "silang jenis". Hal ini hendaknya tidak dipahami dari segi jenis atau seksnya melainkan dari kreativitas seni yang didasarkan atas petimbangan keseimbangan keindahan atau kemungguhan (ketetapan seni). Dari sini dapat dilihat kemampuan seorang penari dalam memerankan tokoh tertentu. Misalnya seorang penari perempuan yang memerankan tokoh Minakjinggo dapat dinilai mungguh jika penari wanita tersebut bisa mengekspresikan karakter tokoh Minakjinggo dengan tampilan yang gagah.

Langendriyan

Mangkunagaran mengalami perkembangan yang lebih pesat daripada Langendriyan Yogyakarta. Hal ini dikarenakan Langendriyan Yogyakarta masih saja ditampilkan diluar tembok keraton sedangkan Langendriyan Mangkunagaran telah menjadi kesenian khas keraton Mangkunagaran.

b. Fase Perkembangan

Dawarwulan

Banyuwangenan

Kesenian yang menampilkan cerita Damarwulan di Banyuwangi dikenal dengan nama Damarwulan dan sekarang popular dengan sebutan Janger. Sebuah gabungan antara seni drama, tari dan musik. Beberapa sumber mengatakan bahwa kesenian Damarwulan di Banyuwangi diciptakan oleh seorang penjual sapi yang bernama Mbah Darji (keturunan Using+Jawa). Pada awalnya Mbah Darji memiliki kesenian Ande-ande Lumut yang banyak menampilkan 
cerita Panji. Mbah Darji bertemu dengan seorang teman bernama Singo yang memperlihatkan perbedaan antara kuluk Praburara dan Ande-ande Lumut. Kemudian Mbah Darji pergi ke Bali untuk mempelajari gamelan dan tari Bali. Di Bali ada kesenian bernama Arja yang dianggap mempunyai nilai yang lebih baik dibanding dengan kesenian Ande-ande Lumut baik dalam hal kostum maupun artistiknya. Setelah beberapa lama mempelajari kesenian Bali dan dianggap sudah menguasainya, Mbah Darji mengajak serta anggota Ande-ande Lumut ke Bali guna mempelajari gamelan dan tarian Bali. Untuk memajukan keseniannya dengan mengadopsi kostum dan gaya tari Bali, pada sekitar tahun 1920-an Mbah Darji mengubah kesenian Ande-ande Lumut menjadi kesenian KARS (Kesenian Agawe Rukun Santoso). Lakon yang dibawakan adalah Bhre Wirabumi Gugat. Pertunjukan pertama KARS digelar di pendopo kelurahan Singonegaran dalam rangka upacara bersih desa.
Masyarakat sangat antusias melihat pertunjukan ini, selain KARS baru pertama manggung pada waktu itu belum banyak tontonan/hiburan seperti sekarang (Suhalik, 2009; Achmad Aksoro, 2003; wawancara dengan Sahuni dan Abdullah Fauzi 22 Juli 2019).

Cerita lain tentang asal-usul Damarwulan dikemukakan oleh Sugiyo. Sugiyo menceritakan pada waktu Sugiyo kecil kesenian Damarwulan disebut tari topeng. Tidak dijelaskan secara rinci asal mula penyebutan tari topeng tersebut. Hal ini sama jika dikaitkan dengan penjelasan Pigeud bahwa sekitar tahun 1914 di daerah Banyuwangi terdapat perkumpulan tari topeng. Pigeud menjelaskan bahwa penduduk setempat kurang berpartisipasi terhadap kesenian yang umumnya bersifat Jawa seperti gamelan, wayang dan tari. Maka dalam pertunjukan tari topeng ini pemainnya adalah pegawai Jawa dari kalangan atas maupun bawah seperti komis, jurutulis, polisi dan lain-lain yang di Banyuwangi 
kebanyakan pendatang dari luar daerah (wawancara dengan Sugiyo, 23 Juli 2019).

Pada 30 Agustus 1930 pemerintah kolonial Belanda yang diwakilkan kepada Wedana Banyuwangi mengundang KARS untuk pentas di pendopo Kawedanan Banyuwangi dalam rangka memperingati hari ulang tahun Ratu Wilhelmina. KARS menampilkan cerita Bhre Wirabumi Gugat. Dari pementasan itulah Wedana Banyuwangi atas perintah Belanda meminta naskah Bhre Wirabumi Gugat dan melarang KARS mementaskan cerita dalam lontar tersebut karena isi dari lontar itu dianggap melawan pemerintah. Sebagai gantinya Wedana Banyuwangi memberikan naskah Damarwulan Ngenger untuk dipentaskan. Naskah tersebut berisikan cerita mulai dari leluhur Minakjinggo sampai dengan Damarwulan Ngenger. Karena KARS hanya diijinkan memainkan cerita Damarwulan, maka orang menyebutnya sebagai kesenian Damarwulan. Pergantian naskah tersebut bertujuan agar masyarakat Blambangan tidak mengenal Wirabumi dan hanya mengetahui bahwa raja Blambangan adalah Minakjinggo yang merupakan pemberontak buruk rupa namun sakti mandraguna (Suhalik, 2009; Aksoro, 2013). Masyarakat Banyuwangi sering menyebut kesenian Damarwulan dengan nama Janger. Hal ini karena adanya pengaruh dari kesenian Bali. Sahuni menjelaskan sebab masyarakat menyebutnya Janger dikarenakan Mbah Darji membawa seorang guru tari Janger dari Bali yang sangat cantik dan lincah dalam menari. Ketika grup Damarwulan Mbah Darji sedang latihan ataupun pentas, banyak warga yang ingin melihat. Mereka berkata "Ayo nonton Janger!". Sebenarnya warga ingin melihat kecantikan dan kepiawaian Niken dalam menari. Kata Damarwulan yang sebenarnya merupakan nama kesenian itu teralihkan oleh kecantikan Niken sebagai penari Janger. Sehingga banyak 
masyarakat Banyuwangi yang menyebut Damarwulan sebagai Janger. Selain itu penyebutan Janger juga dipengaruhi oleh adanya percampuran dengan gaya tari Bali yang mendominasi pertunjukan Damarwulan (wawancara dengan Sahuni 22 Juli 2019). Pelarangan naskah ini merupakan salah satu usaha Belanda untuk melunturkan kepercayaan masyarakat Blambangan terhadap pemimpin dan pemerintah yang masih melakukan perlawanan terhadap Belanda.

Armaya menjelaskan bahwa naskah Bhre Wirabumi Gugat menceritakan tentang ketidakterimaan Bhre Wirabumi atas dilantiknya Tribuana Tungga Dewi sebagai Raja Majapahit. Karena Bhre Wirabumi menganggap seorang wanita tidak pantas menjadi Raja. Akhirnya Bhre Wirabumi memberontak dan menyerang Majapahit. Seperti telah dijelaskan diatas, cerita inilah yang tidak boleh ditampilkan dan diganti dengan cerita Minakjinggo yang gandrung dengan Kenconowungu (Wawancara dengan Armaya, 8 April 2014).

Pigeaud (1938) menyebutkan pada tahun 1930 di kabupaten Banyuwangi tepatnya di daerah Rogojampi terdapat kesenian yang menampilkan cerita Damarwulan dan merupakan tiruan dari cerita rakyat sebelumnya yang menampilkan cerita Ande-ande Lumut. Ande-ande Lumut adalah pertunjukan yang pada waktu itu sudah populer di daerah Jawa Tengah dan biasanya dimainkan oleh masyarakat di daerah pesisir dan Jawa Tengah bagian selatan.

Penduduk yang sengaja didatangkan Belanda dari luar Banyuwangi dengan tujuan awal mencari tenaga kerja untuk membangun Banyuwangi secara tidak langsung juga membawa budayanya ke tempat yang baru. Tidak menutup kemungkinan bahwa Damarwulan adalah kesenian dari daerah Jawa Tengahan yang dibawa oleh para migran karena cerita yang dibawakan memiliki kesamaan 
latar tempat. Kemudian kesenian ini berakulturasi dengan kesenian Jawa, Banyuwangi dan Bali sehingga menghasilkan Janger seperti yang dikenal di Banyuwangi sekarang. Unsur-unsur pertunjukan gaya Bali terlihat pada gerak, kostum dan instrumennya. Unsur Jawa terlihat dari dialognya yang menggunakan bahasa Jawa serta menggunakan tembangtembang Jawa. Bentuk panggungnya juga menyerupai panggung wayang wong atau ketoprak. Unsur Banyuwangi terlihat dalam lawakan atau dagelan yang menggunakan bahasa Using.

Grup Damarwulan mulai muncul pada tahun 1930-an sampai dengan tahun 1980-an. Pertumbuhan grup Damarwulan pada waktu itu bagaikan cendawan di musim hujan. Karena antusiasme masyarakat dalam kesenian ini sangat tinggi, satu desa ada yang mempunyai tiga sampai empat kelompok Damarwulan dan hampir tiap malam mengadakan pentas. Berdirinya grup-grup tersebut dilatarbelakangi oleh sifat kekeluargaan serta naluri untuk menghidupkan seni (Noer, 2003).

Pertumbuhan organisasi Damarwulan pada masa ini dipengaruhi oleh seni pertunjukan profesional yang mengadakan pertunjukan keliling, terutama kelompok-kelompok seni dari kota besar. Pertunjukan keliling ini mengadakan pementasan di wilayah-wilayah perkebunan di daerah Banyuwangi dengan tujuan menghibur para pekerja perkebunan yang umumnya berasal dari luar daerah Banyuwangi dan tentunya rindu dengan kesenian dari daerah asalnya. Biasanya setelah selesai mengadakan pertunjukan di perkebunan, rombongan pertunjukan keliling tersebut mengadakan pentas di pasar malam atau daerah sekitarnya yang dinilai menghasilkan keuntungan yang lebih bagi rombongan (Puspito, 1998).

\section{PENUTUP}

Kesenian Janger di Banyuwangi merupakan akulturasi 
dari Bali, Jawa dan Banyuwangi. Berawal dari cerita DamarwulanMinakjinggo dari Jawa Tengah yang menyebar ke berbagai daerah. Kesenian ini tetap lestari sampai saat ini dikarenakan kecintaan seniman Banyuwangi terhadap seni ini. Pun seniman Janger menggantungkan hidup mereka dari kesenian Janger ini.

\section{DAFTAR PUSTAKA}

Margana, S. 2004. Pujangga Jawa dan Bayang-bayang Kolonial. Yogyakarta: Pustaka Pelajar

Dinas 2019. Rekapitulasi Data Kesenian Se-Kabupaten Banyuwangi.

Suhalik. 2011. Mengenal Sejarah dan Kebudayaan Banyuwangi. Banyuwangi: Pusat Studi Budaya Banyuwangi.

Nurullita, H. 2015. "Stigmatisasi Terhadap Tiga Jenis Seni Pertunjukan di Banyuwangi: Dari Kretivitas Budaya ke Politik". Jurnal Kajian Seni. Volume 2 No. 1.

Zhanah, D.S dan Lutfiati, D. 2017. "Tata Rias Karakter Tokoh Minakjinggo pada Lakon Minakjinggo Nagih Janji dalam Pertunjukan Janger Banyuwangi". E-Journal Unesa. Volume 06 Nomer 01.
Gottschlak, L. 1975. Mengerti Sejarah (terjemahan). Jakarta: Yayasan Penerbitan Universitas Indonesia.

Arifin, W.P. 1995. Babad Blambangan. Yogyakarta: Bentang Budaya.

Muljono, U. (tanpa tahun). "Pendidikan Nilai Luhur Melalui Tembang (Lagu) Dolanan Anak". Laporan penelitian. ISI Yogyakarta.

Widyastutiningrum, S.R. 2006. Langendriyan

Mangkunagaran

Pembentukan dan Perkembangan Bentuk Sajiannya. Surakarta: ISI Press.

Soedarsono. 1999. Seni Pertunjukan Indonesia dan Pariwisata. Bandung: Masyarakat Seni Pertunjukan Indonesia.

Soedarsono. 1979. Beberapa Faktor Penyebab Kemunduran Wayang Wong Gaya Yogyakarta, Satu Pengamatan dari Segi Estetika Tari. Yogyakarta: Proyek ASTI Yogyakarta Departemen Pendidikan dan Kebudayaan.

Achmad Aksoro. 2003. "Asal-usul Cerita DamarwulanMinakjinggo Populer di Banyuwangi”. Jejak. Edisi 4.

Pigeaud, Th. 1938. Javaanse Volksvertonongen Bijdrage tot de Beschrijving van Land en 
Volk. Alih Bahasa oleh K.R.T Muhammad Husodo

Pringgokusumo..

Perpustakaan Rekso Pustoko:

Solo.

Dasuki Noer. 2003. “Upaya

Pelestarian dan

Pengembangan Teater Rakyat

Damarwulan". Jejak. Edisi 4.

Peni Puspito. 1998. "Damarwulan Seni Pertunjukan Rakyat di Kabupaten Banyuwangi Jawa Timur akhir abad 20" Tesis. Universitas Gadjah Mada. 